\title{
In vitro Study of Xanthine Oxidase Inhibitory of Gambir (Uncaria gambir) Hunter Roxb Extracts
}

\author{
Eriawan Rismana1*, Sri Ningsih¹, Fachry Fachrudin²
}

\section{Eriawan Rismana ${ }^{1 *}$, Sri Ningsih', Fachry Fachrudin ${ }^{2}$}

'Center for Pharmaceutical and Medical Technology, Agency for the Asessment and Application of Technology (BPPT), Laptiab Laboratory, 610-611 Building, Kawasan Puspiptek Serpong,

Tangerang, Banten-INDONESIA. ${ }^{2}$ Faculty of Medicine, National Islamic University, Tangerang,

Banten-INDONESIA.

Correspondence

Eriawan Rismana

Center for Pharmaceutical and Medical Technology, Agency for the Asessment and Application of Technology (BPPT) Laptiab Laboratory, 610-611 Building, Kawasan Puspiptek Serpong, Tangerang, Banten-INDONESIA.

Phone no: 6281380802317

E-mail: eriawan.rismana@bppt.go.id

History

- Submission Date: 10-07-2017;

- Review completed: 26-07-2017;

- Accepted Date: 01-08-2017.

DOI : 10.5530/pj.2017.6.135

Article Available online

http://www.phcogj.com/v9/i6

Copyright

() 2017 Phcog.Net. This is an openaccess article distributed under the terms of the Creative Commons Attribution 4.0 International license.

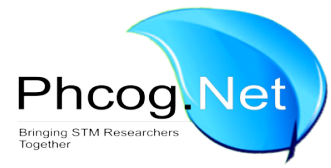

\begin{abstract}
Introduction: Hyperuricemia was a metabolic disorder characterized by high levels of uric acid due to the action of the enzyme xanthine oxidase (XO). Some natural substances with antioxidant activity proved capable of inhibiting the activity of the enzyme XO. Pharmacological benefit of polyphenol compounds had been proved. Gambir (Uncaria gambir) Hunter Roxb, a native plant, had been proved antioxidant activity, so that it had potential to be developed as an inhibitor of the XO. This study aimed to evaluate the activity of Gambir as XO inhibitor. Methods: These extracts of Gambir were preparation from Gambir and Gambir leaf using ethanol 50\% and ethanol 96\%, respectively. The polyphenol content and Xanthine oxidase inhibitory activity was evaluated by spectrophotometry, meanwhile analysis of $(+)$ catechin was determined by high pressure liquid chromatography (HPLC). Results: Screening XO inhibitory activity in vitro showed that ethanolic 96\% extract of Gambir leaf showed the highest activity, i.e. $50 \%$ relative to standard allopurinol at the final concentration of 100 ppm. Conclusion: There was no positive correlation between XO inhibitory activity and polyphenol or $(+)$ catechin content.

Key words: Gambir (Uncaria gambir) Hunter Roxb, Xanthine oxidase, Inhibitory, Polyphenol, (+) Catechin.
\end{abstract}

\section{INTRODUCTION}

Hyperuricemia is a metabolic disorder condition characterized by high levels of uric acid due to xanthine oxidase (XO) activity. The prevalence of patient with hyperuresemia tended to increase every year in line with the rise of economic status of a community. High blood uric acid level and persistent length might progress to chronic gout arthritis in addition to other secondary illnesses.

Uric acid metabolism is carried out by XO enzyme using purines compound as substrate. The metabolism process also produces some radical compounds such as superoxide anion and hydrogen peroxide $\left(\mathrm{H}_{2} \mathrm{O}_{2}\right)$ that cause lipid membrane damage and cell death. Therefore, controlling the XO activity is very important not only to prevent the hyperuricemia but also anticipate the emergence of other secondary illnesses. Polyphenol compounds have been recognized to have beneficial pharmacological effects. Natural product that contained high flavonoid polyphenols demonstrated antioxidant effects and effectively reduced uric acid as well. ${ }^{1,2}$ The effects of antioxidant flavonoid were supposed through scavenging free radical compounds and inhibition of enzymes that produce radical species such as lipoxygenase, cyclooxygenase and xanthine oxidase. ${ }^{3}$

Gambir known as Uncaria gambir belonging to the Rubiaceae family is an Indonesia native plant. ${ }^{4}$ This plant contains polyphenol compound especially flavo- noids $(+)$ catechin that is about $40-80 \%$ of dry water extract weight. ${ }^{5}$ The antioxidant effect of Gambir had been verified in some assay in vitro.$^{6-8}$ However, the efficacy of Gambir as lowering uric acid through $\mathrm{XO}$ inhibitory mechanism in vitro had not been done.

Efforts to explore natural compounds that exhibited $\mathrm{XO}$ inhibitor and antioxidant activity as well were strategic manner in the development of new drug for hyperuricemia treatment. Based on being stated above, this research was aimed to develop Gambir extract that demonstrated XO inhibitory activity

\section{MATERIALS AND METHODS}

Gambir and gambir leaf were collected from local farmer of Payakumbuh Area - West Sumatera - Indonesia. Xanthin oxidase from bovine milk (Sigma, X4376-25UN), xanthine (Sigma, X0626-10G), $\mathrm{NaH}_{2} \mathrm{PO}_{4}$ (Merck), $\mathrm{Na}_{2} \mathrm{HPO}_{4}$ (Merck), bovine serum albumin, DMSO, $\mathrm{NaOH}$,

\section{Experimental}

Preparation of ethanolic extract of gambir and gambir leaf

There were 5 types of samples i.e. ethanolic $96 \%$ and ethanolic $50 \%$ of gambir; ethanolic $96 \%$ and ethanolic 
$50 \%$ of gambir leaf; and gambir extracts that were prepared from gambir and gambir leaf. Two kind of ethanolic gambir extracts were prepared by macerating of dried powder gambir ( $25 \mathrm{~g}$ ) with ethanol 50\% and ethanol $96 \%(250 \mathrm{~mL})$ at room temperature using agitating at $170-180 \mathrm{rpm}$ for 10-15 h., twice. Filtrates collected were evaporated using vacuum machine until dried powder obtained. The two other samples, from powder gambir leaf, were prepared using ethanol $50 \%$ and ethanol $96 \%$ with similar to above method until final semisolid extract gained. All samples were evaluated for inhibition of xanthine oxidase in vitro.

\section{Determination of polyphenol and $(+)$ catechin content}

Determination of polyphenol was spectrophotometric method based on previous studied with slightly modification. ${ }^{9}$ Briefly, into $2.0 \mathrm{~mL}$ disposable plastic microtube, $20 \mathrm{uL}$ of DMSO-dissolved each sample tested (20, 50, $100 \mathrm{ppm}$ final concentration), $1.58 \mathrm{uL}$ aquabidest, $100 \mathrm{uL}$ the Folin-Ciocalteu reagent were put in order and mixed well. After $30 \mathrm{sec}$ to $8 \mathrm{~min}$ left, $300 \mathrm{uL} \mathrm{Na} \mathrm{SO}_{4} 20 \%$ was added to all tubes and shook to mix well for starting the reaction. The reaction was incubated at $40^{\circ} \mathrm{C}$ for $30 \mathrm{~min}$ and read the absorbance of each reaction at $765 \mathrm{~nm}$. Blank solution was prepared by replacing the sample with aquadest. Each experiment was done in triplicate. The standard was prepared by dissolving $0.5 \mathrm{~g}$ gallic acid with $10 \mathrm{~mL}$ ethanol and adding with aquadest until $100 \mathrm{~mL}$ as stock solution. The calibration curve was carried out by diluting gallic acid stock with aquadest into a range of final concentration $1,2,3,5,8$, 10 ppm and then plotting their absorbance vs. concentration to obtain standard curve equation. The concentration of polyphenol was calculated from the equation and reported as percentage of gallic acid equivalent (GAE)/each gram of the extract as following equation: \% polyphenol content $=[\mathrm{ug} / \mathrm{mL} \mathrm{GAE} / \mathrm{ug} / \mathrm{mL}$ extract $] x$ dilution factor $x 100 \%$

Analysis of (+) catechin was based on protocol developed by Center of Pharmaceutical and Medical Technology Laboratory by high pressure liquid chromatography equipped with RP C18 capillary, pump and UV detector. The instrument was from Knauer Technology. Briefly, solution was prepared by dissolving $20 \mathrm{mg}$ of each extract in $1 \mathrm{~mL}$ methanol HPLC-grade by sonication for $5 \mathrm{~min}$. Detection was carried out by measurement of UV absorbance at $279 \mathrm{~nm}$ with eluent-gradient system. The mobile phase composed by acetonitrile/trifluoroacetic acid $0.1 \%$ was established as follow, 1:99 (acetonitrile:trifluoroacetic acid) to 54:46 for 0-12 $\mathrm{min}, 54: 46$ to 1:99 for 12-15 $\mathrm{min}, 1: 99$ for 15-20 min. The mobile phase flow rate was started at $1 \mathrm{~mL} / \mathrm{min}$ and maintained for period experiment. All chromatographic analysis was conducted at $23 \pm 2^{\circ} \mathrm{C}$. A range concentrations of $(+)$ catechin standard $(125,250,500,1000$, $2000 \mathrm{ppm}$ ) were performed as similar above procedures. The (+) Catechin content of each sample was calculated from the regression equation $y=a x+b$ obtained from standard curve.

\section{Determination of Xanthine oxidase inhibitory activity}

Xanthine oxidase inhibitory activity was evaluated by spectrophotometry based on prevoius paper. ${ }^{3}$ Briefly, into $5 \mathrm{~mL}$ quarsa cuvette were put and mixed $100 \mathrm{uL}$ sample solution, $700 \mathrm{~mL}$ phosphat buffer $(\mathrm{pH}=7)$ and $160 \mathrm{uL}$ substrate solution (150 uM substrate xanthine in the same buffer), consecutively. Then, cuvette was incubated at $37^{\circ} \mathrm{C}$ for $5 \mathrm{~min}$. Reaction was commenced by adding $40 \mathrm{uL}$ enzyme solution $(0,3 \mathrm{UI} / \mathrm{mL}$ in the same phosphat buffer) and absorbancy was measured at $290 \mathrm{~nm}$ after 1 min. Absorbance reading was repeated at 1, 2, 3 min thereafter. Control enzyme and blank solutions were prepared by replacing sample with phosphat buffer and enzyme solution with phosphat buffer, respectively. The slope was calculated from curve related between concentration v.s. absorbance using microsoft excell program. Each experiment was conducted in triplicate. Allopurinol at the same above concentration was used as standard. Percentage of inhibition was calculated with this equation: \% inhibition $=[($ control slope - sample slope $) /$ control slope $] \times 100 \%$

\section{RESULTS AND DISCUSSION}

\section{Preparation of ethanolic extract of gambir and gambir leaf}

The experiments obtained 5 types of samples i.e. ethanolic $96 \%$ and ethanolic $50 \%$ of gambir; ethanolic $96 \%$ and ethanolic $50 \%$ of gambir leaf; and gambir. The recovery of each extraction was influenced by the type of solvent and extracted sample as presented in Table 1.

The ethanolic 96\% extract of gambir and gambir leaf demonstrated slightly more rendement to compare with ethanolic $50 \%$ extract of gambir and gambir leaf. These results showed that the polarity of compounds at gambir and gambir leaf were almost similar to ethanol $96 \%$ compared than ethanol $50 \%$. Meanwhile, both gambir extracts that were processed from gambir provided a higher recovery rate compared to gambir leaf, this was due to gambir leaf contain cellulose and others compound that was difficult to dissolve in both eluents used.

\section{Determination of polyphenol and (+)catechin content}

Polyphenol and $(+)$ catechin contents of each sample was depicted at Figure 1. The polyphenol showed that samples that prepared from gambir contained polyphenol compounds higher than those of gambir leaf. The ethanolic $96 \%$ extract of gambir demonstrated the highest polyphenol content followed in the decreasing order gambir > ethanolic 50\% extract of gambir > ethanolic $96 \%$ extract of gambir leaf > ethanolic $50 \%$ extract of gambir leaf. These results showed that the polarity of polyphenol compounds were almost similar to ethanol $96 \%$ compared than ethanol $50 \%$. The (+) catechin content of samples was showed that the solubility of this compound was higher in ethanol $96 \%$ eluent than ethanol $50 \%$ one. It was displayed that three samples that prepared from gambir were higher than those of from gambir leaf ones. (+) Catechin content was decreased in the following order ethanolic $96 \%$ extract of gambir $=$ gambir $>$ ethanolic $50 \%$ extract of gambir > ethanolic $96 \%$ extract of gambir leaf $>$ ethanolic $50 \%$ extract of gambir leaf. These results showed that the polarity of $(+)$ catechin were almost similar to ethanol $96 \%$ compared than ethanol $50 \%$.

The percentage of xanthine oxidase inhibitory of five samples was showed at Figure 2. Based on Figure 2, it was showed that both extracts from gambir leaf demonstrated xanthine inhibitory activity higher than three extracts from gambir. The highest inhibitory activity was showed at ethanolic $96 \%$ extract of gambir leaf (50\%) followed by ethanolic $50 \%$ extract

Table 1: Rendement of extraction each sample

\begin{tabular}{ccccc}
\hline Samples & $\begin{array}{c}\text { Initial } \\
\text { weight } \\
(\mathbf{g})\end{array}$ & $\begin{array}{c}\text { Extract } \\
\text { weight } \\
\text { obtained } \\
\text { (g) }\end{array}$ & $\begin{array}{c}\text { Rendement } \\
(\%)\end{array}$ & Final mass \\
\hline $\begin{array}{c}\text { Ethanolic 96\% } \\
\text { extract of gambir } \\
\text { leaf }\end{array}$ & 25.0 & 4.0 & 16.00 & $\begin{array}{c}\text { Semisolid, } \\
\text { dark brownish }\end{array}$ \\
$\begin{array}{c}\text { Ethanolic 50\% } \\
\text { extract of gambir } \\
\text { leaf }\end{array}$ & 25.0 & 3.2 & 12.80 & $\begin{array}{c}\text { Semisolid, } \\
\text { dark brownish }\end{array}$ \\
$\begin{array}{c}\text { Ethanolic 96\% } \\
\text { extract of gambir }\end{array}$ & 25.0 & 19.1 & 76.40 & $\begin{array}{c}\text { Solid, light } \\
\text { brownish } \\
\text { Ethanolic 50\% }\end{array}$ \\
extract of gambir & 25.0 & 16.7 & 66.80 & $\begin{array}{c}\text { Solid, light } \\
\text { brownish }\end{array}$ \\
\hline
\end{tabular}




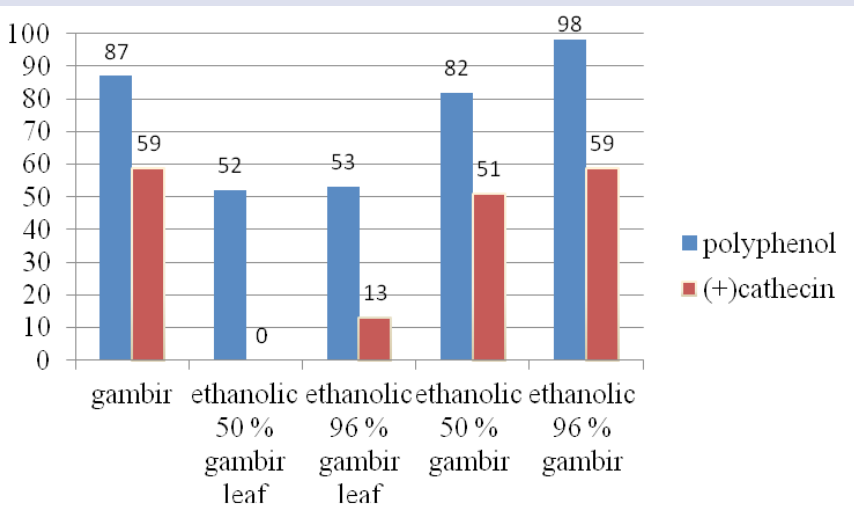

Figure 1: Percentage of polyphenol and $(+)$ catechin content of each extract.

of gambir leaf (47\%). Meanwhile, three extracts from gambir showed similar inhibitory activity, about 17-18\%.

This study was initialized by screening activities toward five types of samples (two samples from gambir leaf and three samples from gambir) to define a selected sample with the best of XO inhibitory. Furthermore, the selected sample could be used not only to suppress the action of the $\mathrm{XO}$ enzyme XO, but also to occupy free radical as by product of XO. Both extracts that were obtained from gambir leaf showed that XO inhibitory activity of ethanolic $96 \%$ extract of gambir leaf was higher than those of ethanolic 50\% extract one. Meanwhile, polyphenol content of both extracts was not different significantly. Figure 1 showed that polyphenol content of ethanolic $96 \%$ extract and ethanolic 50\% extract of gambir leaf were $53 \%$ vs $52 \%$, respectively. Analysis of XO inhibitory activity was also slightly different from both extracts, i.e. 50\% (ethanolic 96\% extract) and $47 \%$ (ethanolic 50\% extract), respectively. It was supposed that $\mathrm{XO}$ inhibition was not caused by polyphenol compounds contained in the extract.

However, $(+)$ catechin compound as the mayor compounds in extract and polyphenol compound of gambir did not provide the dominant contribution of this effect. ${ }^{5}$ This was indicated in ethanolic $50 \%$ extract that even though the levels of this compound were not detected, this sample still demonstrated anti-XO activity that was almost similar to ethanolic $96 \%$ extract of gambir leaf that contained $13 \%$ of $(+)$ catechin. These results were in line with previous study. Cos P. et al. stated that the activity of XO inhibitor depended on number and position of hydroxyl group. ${ }^{10}$ The hydroxyl groups at C-5 and C-7 and the double bound between C-2 and C-3 of flavonoid structure were the main contributed for a high anti-XO activity. These hydroxyl groups were not founded in $(+)$ catechin structure.

Xanthine oxidase action was not only influenced by polyphenol compounds, but also other compounds contributed to $\mathrm{XO}$ inhibition. Samples were plant-derived extract that contained complex chemical compounds in which their activity was a combination from the effect of each compound. Each compound might deliver synergism effects and decreased the risk effect or otherwise produced unfavorable effect so that the final biological activity was produced from the well-balanced efficacy from total compound. ${ }^{11}$ Previous study exhibited that there were some compounds found in gambir extract such as $(+)$ epicathecin 1,5\%, gambiriin $\mathrm{B} 1, \mathrm{~B} 3, \mathrm{~A} 1$ about $1 \%$, respectively; alkaloid, saponin, tanic

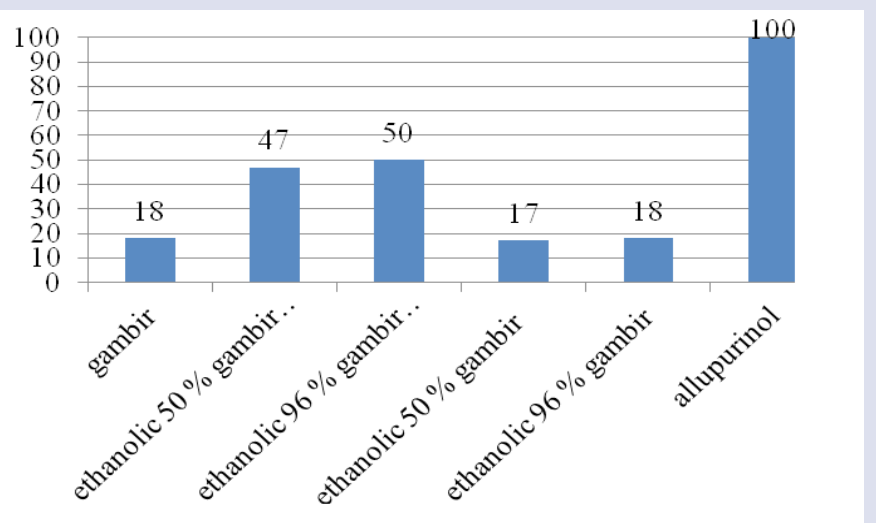

Figure 2: Percentage of $\mathrm{XO}$ inhibitory activity of each extract.

acid, pyrocatecol, florisin, fat, and fixed oil..$^{12,13}$ It was most likely that these compounds contribute to the XO inhibitory activity.

Three samples obtained from gambir (ethanolic 96\% extract of gambir, ethanolic 50\% extract of gambir and gambir) showed that anti-XO activities of these samples were not different to each other, namely, about $17-18 \%$. Meanwhile, the levels of polyphenols content were in descending order ethanolic $96 \%$ extract > gambir > ethanolic 50\% extract. It was demonstrated that they were not produced a positive correlation between XO inhibitory activities and polyphenols level. Polyphenol compounds contained in the extract did not main contribute in this activity.

Subsequently, it was demonstrated that both samples obtained from gambir leaf exhibited anti-XO activity much more active than three samples from gambir. This was likely due to the chemical compounds contained gambir was wasted during gambir processing. To obtain gambir gum, it was needed decantation process for a night and then the water on the surface was separated. Gum deposited was dried until dried powder obtained. Another possibility was the chemical compounds contained in gambir be damaged that was caused by the use of steam during gambir processing.

\section{CONCLUSION}

The study has shown that the ethanolic 95\% extract of gambir leaf demonstrated the highest XO inhibitory activity. The XO inhibitory action was demonstrated that they were not produced a positive correlation between polyphenol and $(+)$ cathecin contents.

\section{ACKNOWLEDGEMENT}

Authors would like to thank to Director of The Center of Pharmaceutical and Medical Technology - Agency for the Assesment and Application of Tecgnology for providing and supporting facilities to conduct these research and Insentif Sinas Ristek 2014 - 2015 Program for providing this research funding.

\section{CONFLICT OF INTEREST}

There is no conflict of interest.

\section{ABBREVIATION USED}

XO: Xanthine oxidase; GAE: Gallic acid equivalentl; UV: Ultraviolet, HPLC: High Performance Liquid Chromatography; RP: Reverse Phase. 


\section{REFERENCES}

1. Spanou C, Veskoukis AS, KerasiotiT, Kontou M, Angelis A, Aligiannis N. Flavonoid Glycosides Isolated from Unique Legume Plant Extracts as Novel Inhibitors of Xanthine Oxidase. PLoS ONE, March. 2012;7(3):e32214.

2. Hanaee J, Rashidi MR, Delazar A, Piroozpanah S. Onion, a Potent Inhibitor of Xantine Oxidase. Iranian Journal of Pharmaceutical Research. 2004;4:243-7.

3. Dew TP, Day AJ, Morgan MRA. Xanthine Oxidase Activity in vitro: Effects of Food Extracts and Components. J. Agric. Food Chem. 2005;53(16):6510-5.

4. Hussin $\mathrm{MH}$, Kassim MJ. The corrosion inhibition and adsorption behavior of Uncaria gambir extract on mild steel in $1 \mathrm{M} \mathrm{HCl}$. Materials Chemistry and Physics. 2011;125(3):461-8.

5. Hayani E. Analysis of Catechin in Gambir Using Some Methodes Buletin Teknik Pertanian. 2003;8(1):31-3.

6. Amir M, Mujeeb M, Khan A, Ashraf K, Sharma D, Aqil M. Phytochemical analysis and in vitro antioxidant activity of Uncaria gambir. International Journal of Green Pharmacy. 2012;6(1):67-72.

7. Anggraini T, Akihiro T, Yoshino T, Itani T. Antioxidative activity and catechin content of four kinds of Uncaria gambir extracts from West Sumatra Indonesia.
African Journal of Biochemistry Research. 2011;5(1):33-8.

8. Widiyarti G, Sundowo A, Hanafi M. The free radical scavenging and anti-hyperglycemic activities of various gambiers available in indonesian market. Makara Sains, November. 2011;15(2):129-34.

9. Waterhouse A. Folin-ciocalteau micro method for total phenol in wine. Waterhouse Lab, University of California. Available from: http://waterhouse.ucdavis edu/faqs/davis-info.

10. Cos P, Ying L, Calomme M, Hu JP, Cimanga K, Poel BV, et al. Structure-Activity Relationship and Classification of Flavonoids as Inhibitors of Xanthine Oxidase and Superoxide Scavengers. J. Nat. Prod. 1998;61(1):71-6.

11. Ningsih S, Fachrudin F, Rismana E, Purwaningsih EH, Sumaryono W, Jusman SW. Evaluation of Antilipid Peroxidation Activity of Gambir Extract on Liver Homogenat In vitro International. Journal of PharmTech Research July-Aug 2014;6(3):982-9

12. Bahtiar A. The Potency of Gambir as Raw Material Drug, Cosmetic and Health Drinks, Pokjanas TOI 44, Palembang. Indonesia. 2013

13. Taniguchi S, Kuroda K, Doi K, Inada K, Yoshikado N, Yoneda Y, et al. Exaluation of Gambir Quality Based on Quantitative Analysis of Polyphenolic Constituents. Yakugaku Zasshi. 2007:127(8):1291-300.

\section{GRAPHICAL ABSTRACT}

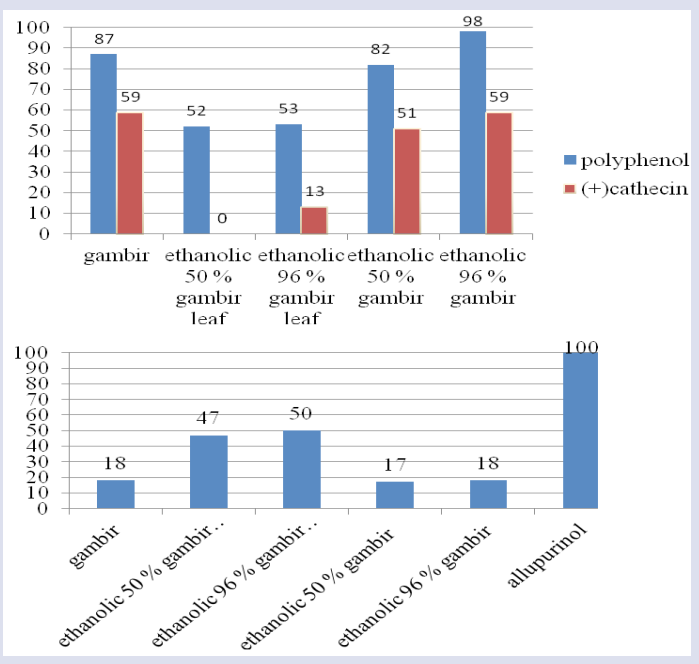

\section{SUMMARY}

- This paper reported the preparation of Gambir extracts, determination of polyphenol and (+)cathecin and Xan $\neg$ thine oxidase inhibitor from these extracts

- The study has shown that the ethanolic $95 \%$ extract of gambir leaf demonstrated the highest XO inhibitory activity.

- The XO inhibitory action was demonstrated that they were not produced a positive correlation between polyphenol and $(+)$ cathecin contents.

\section{ABOUT AUTHORS}

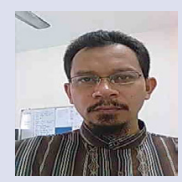

Eriawan Rismana: Researcher at Center for Pharmaceutical and Medical Technology, Agency for the Asessment and Application of Technology (BPPT), Laptiab Laboratory, 610-611 Building, Puspiptek Serpong, Tangerang, Banten - Indonesia

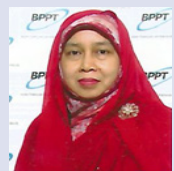

Sri Ningsih: Researcher at Center for Pharmaceutical and Medical Technology, Agency for the Asessment and Application of Technology (BPPT), Laptiab Laboratory, 610-611 Building, Puspiptek Serpong, Tangerang, Banten - Indonesia.

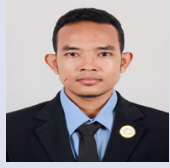

Fachry Fachrudin: Lecturer at Faculty of Medicine, National Islamic University, Tangerang , Banten - Indonesia.

Cite this article: Rismana E, Ningsih S, Fachrudin F. In vitro Study of Xanthine Oxidase Inhibitory of Gambir (Uncaria gambir) Hunter Roxb Extracts. Pharmacog J. 2017;9(6):862-5. 